\title{
KAJIAN MACAM JARAK TANAM SISTEM JAJAR LEGOWO DAN VARIETAS TERHADAP PERTUMBUHAN DAN PRODUKSI TANAMAN PADI (Oryza Sativa L.)
}

\author{
Study Of Kinds Of Legowo And Variety Plant Systems For Growth And Production \\ Of Padi Plants (Oryza Sativa L.)
}

Istiqomah, Ana Amiroh, Dwi Choiriyah, dan Suharso

Fakultas Pertanian Universitas Islam Darul Ulum Lamongan

Korespondensi : istiqomah.faqih@gmail.com

\begin{abstract}
ABSTRAK
Rice is a rice-producing food crop which now plays an important role in economic life in Indonesia. Namely rice as a staple food is very difficult to replace by other staples. Among them are corn, tubers, sago and other carbohydrate sources. So that the existence of rice is now a top priority for the community in meeting the needs of carbohydrate intake that can be filling and is a source of primary carbohydrates that are easily replaced into an energy source. Rice as a staple food is consumed by approximately $90 \%$ of the total population in Indonesia for daily essential food (Saragih,2001). How to plant with the jajar legowo system has the advantage that the plants are on the edge so that optimal sunshine can cause plant productivity to be high, facilitate weed control and pests / diseases, use of fertilizer more effectively and the availability of empty space for regulating water channel circulation on land (Sirrapa, 2011). This research was conducted using Factorial Randomized Block Design (RBD) method, which consisted of two factors and each factor consisting of 3 levels repeated 3 times, namely: J1: Conventional,J2: Jajar Legowo 2: 1,J3: Jajar Legowo 4: 1. Factor II: Varieties with 3 levels, V1: Situ Bagendit, V2: Ciherang,V3: IR-64. Of the two factors 9 combinations of treatments were obtained and repeated 3 times. Data obtained from observations were calculated by analysis of variance with the Fisher test (-F test at the level of $5 \%$ and $1 \%$ ), if there were significant differences, it would be followed by the Smallest Significant Difference test (LSD 5\%). The treatment of the legowo 4: 1 row system and the ciherang variety (V2J3) produces a better value than other treatments.
\end{abstract}

Keywords: jajar legowo, varieties, rice

\section{PENDAHULUAN}

umbi-umbian, sagu dan sumber karbohidrat lainnya. Sehingga keberadaan beras sekarang menjadi prioritas utama bagi masyarakat dalam memenuhi kebutuhan asupan karbohidrat yang dapat mengenyangkan dan merupakan sumber karbohidrat utama yang mudah diganti menjadi sumber energi. Padi sebagai tanaman pokok pangan yang diminati lebih dari 90 persen dari semua masyarakat di Indonesia untuk makanan penting seharihari (Saragih,2001).

Kemampuan dan Ketersediaan pangan di Indonesia dinilai belum kuat. Karena itu di sebabkan oleh tingginya angka impor pada produk pangan. Sampai tahun 2013 masalah ketrersediaan pangan khususnya beras menjadi masalah besar bagi bangsa Indonesia. Pada tahun 2011, impor beras 1,6 jt ton dan tahun 2012 impor beras 1,9 jt ton menurut (Pujiasmanto, 2013). 
Cara tanam menggunakan sistem pola tanam jajar legowo mempunyai keuntungan yaitu tanaman yang berada di bagian pinggir bisa mendapatkan sinar matahari yang maksimal yang mengakibatkan produktivitas tanaman padi menjadi bagus, memudahkan dalam pengendalian OPT, penggunaan pupuk menjadi muda dan adanya ruang untuk pengaturan sirklus saluran air pada lahan (Sirrapa, 2011).

Sistem pola tanam jajar legowo adalah sistem tanam yang sangat mengutamakan pada larikan tanaman, sistem tanam jajar legowo ialah tanam yang berselang antara 2 atau lebih baris tanaman padi dan satu barisan kosong. Kelebihan dari penanaman sistem pola tanam jajar legowo dapat jadikan pada semua tanaman lebih banyak tanaman menjadi tanaman pinggir. Tanaman pinggir akan mendapatkan sinar matahari yang cukup dan sirkulasi udara menjadi baik, unsur hara tanaman lebih merata, serta menjadi lebih mudah merawat tanaman.

Menurut Suparwoto (2010) faktor penting penentu peningkatan tanaman padi adalah dengan sistem tanam pindah.

Dengan jarak tanam yang rapat biaya pada penanaman padi menjadikan produksi sangat meningkat dan apabila lebar populasi tanaman menjadi menurun pada akhirnya mengakibatkan hasil panen menurun dan merugi.

\section{METODE PENELITIAN}

Waktu dan Tempat. Penelitian ini dilaksanakan di Desa sendangrejo kecamatan lamongan Kabupaten Lamongan. Ketinggian tempat \pm 4 meter dpl. Waktu penelitian di mulai pada bulan januari sampai april 2019.

\section{Bahan dan Alat.}

Bahan yang dibutuhkan pada penelitian ini adalah benih tanaman padi. Verietas situ bagendit, ceherang, IR-64, pupuk urea.
Alat alat yang di gunakan yaitu cangkul, tugal, ajir, alat pengukur, meteran, timbangan, papan nama, alat tulis dan peralatan lain.

\section{Metode Penelitian.}

Penelitian dilaksanakan dengan metode Rancangan Acak Kelompok (RAK) Faktorial, terdiri dari dua factor, setiap faktor terdri dari 3 level yang diulang 3 kali ulangan, yaitu:

Faktor I : macam jarak tanam dengan 3 level :

$$
\begin{array}{ll}
\text { J1 } & \text { : Konvensional } \\
\text { J2 } & \text { : Jajar Legowo 2:1 } \\
\text { J3 } & \text { : Jajar Legowo 4:1 }
\end{array}
$$

Faktor II : Varietas dengan 3 level

$\begin{array}{ll}\text { V1 } & \text { : Situ Bagendit } \\ \text { V2 } & \text { : Ciherang } \\ \text { V3 } & \text { : IR-64 }\end{array}$

Dari kedua faktor tersebut diperoleh 9 kombinasi perlakuan dan diulang 3 kali. Data yang diperoleh dari hasil pengamatan dihitung dengan analalisa sidik ragam menggunakan uji Fisher (uji $-\mathrm{F}$ dari taraf $5 \%$ dan $1 \%$ ), apabila terjadi perbedaan nyata maka akan dilanjutkan menggunakan uji Beda Nyata Terkecil (BNT 5\%).

\section{HASIL DAN P EMBAHASAN}

Dari hasil analisis ragam menunjukkan bahwa adanya interaksi antara perlakuan sistem tanam jajar legowo dan macam varietas terhadap tinggi tanaman pada parameter pengamatan $7,21,35$, dan 49 hst.

Tabel 2, dapat dilihat bahwa parameter tinggi tanaman menunjukkan intraksi perlakuan macam varietas (v2) dan sistim jajar legowo (J3). Hasil pertumbuhan tinggi tanaman yang baik dibandingkan pada perlakuan yang lain terdapat pada pengamatan umur 7 hst, 21 hst, 35 hst dan 49 hst.

Menurut Suprihatno menyatakan bahwa tinggi rendahnya batang tanaman di akibatkan karena sifat yang mempengaruhi daya hasil varietas. 
Berdasarkan karakteristik tinggi tanaman varietas yang memiliki tinggi tanaman pendek dapat diakibatkan oleh beberapa faktor seperti faktor iklim ataupun faktor lainnya. Semakin tinggi tanaman semakin tinggi pula terjadinya untuk rebah. varietas yang mempunyai batang yang pendek lebih banyak menyerap sinar berbeda dengan penyerapan sinar matahari oleh varietas yang tinggi. Dengan batang yang panjang, intensitas sinar matahari yang melebihi kanopi (tajuk) tanaman ke bagian bawah pertanaman di atas permukaan tanah akan jauh berkurang.

Tabel 1 . Rata-rata Tinggi Tanaman (cm) Pada Umur 7, 21, 35 dan 49 Hst.

\begin{tabular}{|c|c|c|c|c|}
\hline \multirow{2}{*}{ Perlakuan } & \multicolumn{4}{|c|}{ Rata-rata Tinggi Tanaman $(\mathrm{cm})$ pada Pengamatan Umur } \\
\hline & 7 hst & 21 hst & 35 hst & $49 \mathrm{hst}$ \\
\hline V1J1 & $37.33 \mathrm{bcd}$ & 45.43 ef & $63.49 \mathrm{bcd}$ & $86.26 \mathrm{bcd}$ \\
\hline V1J2 & $37.80 \mathrm{bcd}$ & 46.57 cde & $63.10 \mathrm{bcd}$ & $84.97 \mathrm{~d}$ \\
\hline V1J3 & $36.80 \mathrm{~d}$ & $44.07 \mathrm{f}$ & $61.37 \mathrm{~cd}$ & $85.77 \mathrm{bcd}$ \\
\hline V2J1 & $38.80 \mathrm{bc}$ & $44.12 \mathrm{f}$ & $64.07 \mathrm{bc}$ & $86.76 \mathrm{bcd}$ \\
\hline $\mathrm{V} 2 \mathrm{~J} 2$ & $39.00 \mathrm{~b}$ & $44.48 \mathrm{f}$ & 64.50 a & $86.73 \mathrm{bcd}$ \\
\hline V2J3 & $44.60 \mathrm{a}$ & 53.87 a & 71.29 ba & 92.80 a \\
\hline V3J1 & $38.27 \mathrm{bcd}$ & $48.59 \mathrm{~b}$ & $63.77 \mathrm{bcd}$ & $85.45 \mathrm{bcd}$ \\
\hline V3J2 & $38.40 \mathrm{bcd}$ & $47.89 \mathrm{bcd}$ & $63.19 \mathrm{bcd}$ & $85.55 \mathrm{bcd}$ \\
\hline V3J3 & $38.20 \mathrm{bcd}$ & 48.39 bc & $62.36 \mathrm{bcd}$ & $86.23 \mathrm{bcd}$ \\
\hline BNT 5\% & 0.01 & 2.02 & 2.68 & 2.70 \\
\hline
\end{tabular}

Keterangan : Angka-angka yang diikuti oleh huruf yang sama dalam kolom yang sama tidak berbeda nyata dengan uji BNT $5 \%$.

Nursanti (2009) menambahkan pertambahan tinggi tanaman ini di sebabkan karena tajuk tanaman yang sangat rapat mengakibatkan kualitas cahaya yang di terima menjadi menurun. Semakin dekat jarak tanam yang di pakai maka pertumbuhan tinggi pada tanaman akan semakin cepat karena tanaman saling berusaha mencari sinar matahari, Namun itu adalah faktor penentu terjadinya pertumbuhan tanaman padi. Faktor lain yang bisa mempengaruhi yaitu kondisi lahan, cuaca dan iklim di tempat penelitian, dan gen dari varietas itu sendiri.

Menurut Aribawa (2012), menyatakan bahwa semakin tinggi tanaman lebih tinggi pula dihasilkannya pada populasi tanaman yang lebih banyak dalam satu hamparan lahan/tampat penelitian. Pertumbuhan tanaman yang tinggi belum menjamin produktivitas tanaman juga tinggi. Tanaman yang tumbuh baik mampu menyerap hara dalam jumlah banyak, ketersediaan hara dalam tanah berpengaruh terhadap aktivitas tanaman termasuk aktivitas fotosintesis, sehingga dengan demikian tanaman menjadi meningkat hasil pertumbuhan dan produksinya.

\section{Jumlah Banyak Anakan}

Hasil analisis ragam menunjukan bahwa terdapat adanya interaksi antara perlakuan terhadap sistem pola tanam jajar legowo dan macam varietas terhadap jumlah anakan pada umur pengamatan 21,35 , dan 49 hst.

Pada tabel 3, diatas menunjukkan bahwa pengamatan para meter jumlah anakan menunjukkan interaksi perlakuan macam varietas (V2) dan sistim tanam jajar legowo (J3). Hasil pertumbuhan jumlah anakan yang baik terdapat pada pengamatan umur 35 dan 49 hst. Jika jarak tanam yang di gunakan semakin lebar, maka maka akan menghasilkan jumlah anakan yang banyak. 
Tabel 2 . Rata-rata Jumlah Anakan Pada Umur 21 hst, 35 Hst dan 49 Hst.

\begin{tabular}{cccc}
\hline \multirow{2}{*}{ Perlakuan } & \multicolumn{3}{c}{ Rata-rata Tinggi Tanaman (cm) pada } \\
& \multicolumn{3}{c}{ Pengamatan umur } \\
\cline { 2 - 4 } V1J1 & $10.87 \mathrm{hst}$ & $35 \mathrm{hst}$ & $49 \mathrm{hst}$ \\
V1J2 & $11.60 \mathrm{~b}$ & $17.93 \mathrm{bc}$ & $21.60 \mathrm{~b}$ \\
V1J3 & $10.73 \mathrm{bcd}$ & $16.97 \mathrm{bc}$ & $21.40 \mathrm{~b}$ \\
V2J1 & $11.13 \mathrm{bcd}$ & $17.60 \mathrm{bc}$ & $21.93 \mathrm{~b}$ \\
V2J2 & $10.33 \mathrm{bcd}$ & $18.30 \mathrm{abc}$ & $21.20 \mathrm{~b}$ \\
V2J3 & $15.47 \mathrm{a}$ & $21.10 \mathrm{a}$ & $26.07 \mathrm{a}$ \\
V3J1 & $10.27 \mathrm{bcd}$ & $17.13 \mathrm{bc}$ & $22.13 \mathrm{~b}$ \\
V3J2 & $9.93 \mathrm{~cd}$ & $16.43 \mathrm{c}$ & $21.80 \mathrm{~b}$ \\
V3J3 & $9.67 \mathrm{~cd}$ & $15.50 \mathrm{c}$ & $21.67 \mathrm{~b}$ \\
\hline BNT 5\% & 1.36 & 2.85 & 1.82 \\
\hline
\end{tabular}

Keterangan : Angka-angka yang diikuti oleh huruf yang sama dalam kolom yang sama tidak berbeda nyata dengan uji BNT 5\%.

Hasil dari Sidik ragam menunjukan penggunaan sistem tanam pola jajar legowo 4:1 menghasilkan anakan yang lebih banyak, berbeda dengan menggunakan pola tanam konvensional dengan pola tanam jajar legowo 2:1. Hal ini diduga disebabkan populasi tanaman yang terlalu rapat pada pola tanam konvensional dan pola jajar legowo 2:1 sehingga menghasilkan anakan yang lebih sedikit, dibandingkan dengan penanaman padi pada pola tanam sistem jajar legowo 4:1. Selain pengaruh kerapatan populasi pada sistem tanam, pembentukan anakan juga dipengaruhi oleh sifat genetik dan keadaan lingkungan yang sesuai dengan pertumbuhan tanaman.

Menurut Husana (2010), jumlah anakan akan maksimal apabila tanaman memiliki sifat genetik yang baik di tambah dengan keadaan lingkungan yang menguntungkan atau sesuai dengan pertumbuhan dan perkembangan tanaman. Selanjutnya di jelaskan bahwa pada jumlah anakan maksimal juga di tentukan pada jarak tanam, karena pada jarak tanam menentukan radiasi matahari, unsur hara mineral serta budidaya tanaman itu sendiri. faktor genetik dan lingkungan juga menentukan produktivitas padi tersebut.

Menurut Hatta (2012), penangkapan cahaya matahari pada jarak tanam lebar dapat meningkatkan jumlah anakan produktif, berat gabah per rumpun dan bobot kering tanaman. Penggunaan bibit umur muda juga berpengaruh pada peningkatan berat kering tanaman. Hal tersebut sesuai dengan penelitian.hal ini sejalan dengan penelitian Christanto (2014), menjelaskan bahwa tingginya hasil persatuan luas tanaman padi tidak secara nyata didukung oleh pertumbuhan vegetatif seperti pada jumlah anakan maksimum maupun jumlah anakan produktif/rumpun. Hal tersebut sejalan dengan penelitian Pratiwi et.al. (2010) menjelaskan semakin banyak populasi pada tanaman, maka semakin sedikit jumlah anakan. Pada populasi tanaman yang lebih sedikit, maka pertumbuhan rumpun tanaman lebih tinggi namun hasil per luasan lahan lebih rendah dibandingkan jarak tanam yang lebih rapat. Ikhwani, et al. (2013), juga menjelaskan bahwa pola tanam pada jajar legowo berpeluang menghasilkan gabah lebih tinggi dibandingkan pola tanam pindah karena populasi yang lebih banyak.

\section{Berat Gabah Basah Persampel}

Pada hasil analisis ragam menunjukkan bahwa terdapat interaksi antara perlakuan pada macam varietas dan pola sistem jajar legowo terhadap berat gabah basah per sampel pada umur panen

Pada Tabel 4, menunjukkan bahwah berat gabah basah per sampel menunjukkan interaksi pada perlakuan macam varietas (V2) dan sistim jarak tanam jajar legowo (J3). Nilai tertinggi untuk berat gabah basah per sampel sebesar 4.17 (g). Hal ini dikarenakan pada masa awal penanaman sampai fase pertumbuhan banyak tanamn yang hidup sehingga kompetisi antara tanaman baik dalam unsure hara maupun cahaya tidak ter 
lalu tinggi yang menyebabkan pembagian hasil fotosintesis untuk pengisian bulir malai menjadi lebih efisien.

Ikhwan et al. (2013) menjelaskan pada sistem pertanaman rapat, termasuk sistem tanam pola jajar legowo, persaingan perakaran tanaman dalam menyerap air dan unsur hara berlangsung secara intensif sehingga produksi yang dihasilkan akan rendah.

\begin{tabular}{cc}
\hline Perlakuan & $\begin{array}{c}\text { Rata-rata berat gabah } \\
\text { basah per sampel (g) pada } \\
\text { pengamatan umur panen }\end{array}$ \\
\hline V1J1 & $2.84 \mathrm{cdef}$ \\
V1J2 & $2.95 \mathrm{cdef}$ \\
V1J3 & $3.37 \mathrm{cde}$ \\
V2J1 & $3.20 \mathrm{cdef}$ \\
V2J2 & $3.77 \mathrm{a}$ \\
V2J3 & $4.17 \mathrm{ba}$ \\
V3J1 & $3.44 \mathrm{bc}$ \\
V3J2 & $3.43 \mathrm{~cd}$ \\
V3J3 & $2.54 \mathrm{f}$ \\
\hline BNT\% & 0.68 \\
\hline
\end{tabular}

Keterangan : Angka-angka yang diikuti oleh huruf yang sama dalam kolom yang sama tidak berbeda nyata dengan uji BNT 5\%.

Azwir (2008) menyatakan bahwa keunggulan pada sistem pola tanam jajar legowo ialah dengan adanya ruang kosong setiap 2 atau 4 baris setiap tanaman sehingga bisa memberi sirkulasi udara, pemasukan cahaya dan juga aliran air dan penyebaran pada unsur hara yang lebih merata sehingga tampilan pertumbuhan dan komponen hasil yang dihasilkan juga akan semakin lebih baik sesuai dengan urutan kerapatan legowo yang dilakukan.

\section{Berat Gabah Basah Per Hektar}

Hasil analisis ragam menunjukkan bahwa terdapat interaksi antara perlakuan macam varietas dan sistem jajar legowo terhadap berat gabah basah per sampel pada umur panen
Tabel 4 . Rata-rata Berat Gabah Basah (t) Per hektar

\begin{tabular}{cc}
\hline Perlakuan & $\begin{array}{c}\text { Rata-rata berat gabah basah (t) } \\
\text { per hektar pada pengamatan } \\
\text { umur panen }\end{array}$ \\
\hline V1J1 & $7.17 \mathrm{cdef}$ \\
V1J2 & $7.40 \mathrm{cdef}$ \\
V1J3 & $8.40 \mathrm{bcd}$ \\
V2J1 & $8.00 \mathrm{bcde}$ \\
V2J2 & $9.37 \mathrm{ab}$ \\
V2J3 & $10.40 \mathrm{a}$ \\
V3J1 & $8.57 \mathrm{bc}$ \\
V3J2 & $8.57 \mathrm{bc}$ \\
V3J3 & $6.30 f$ \\
\hline BNT\% & 1.69 \\
\hline Keterangan & $:$ Angka-angka yang dikuti oleh huruf \\
yang sama dalam kolom yang sama tidak berbeda \\
nyata dengan uji BNT 5\%.
\end{tabular}

Pada Tabel 4, Sidik ragam menyimpulkan bahwa pada pola tanam sistem jajar legowo berpengaruh nyata. Hasil uji BNT bahwa penggunaan pola tanam sistem jajar legowo 4:1 memberikan hasil gabah per hektar lebih tinggi berbeda dengan pola tanam sistem jajar legowo pada perlakuan lainnya, Hal ini diduga karena disebabkan banyaknya gabah yang berisi dari pada gabah yang hampa pada pola tanam sistem jajar legowo 4:1 sehingga dapat menghasilkan gabah per hektar lebih tinggi dibandingkan pola tanam sistem jajar legowo 2:1 dan pola tanam sistem konvensional.

Menurut Salahuddin dkk. (2009) memaparkan jarak tanam mempengaruhi panjang malai, jumlah bulir per malai, dan hasil per ha tanaman padi. Hal ini diduga disebabkan efek dari sistem jajar legowo, dimana tanaman cukup mendapat suplai nutrisi, air dan sinar matahari. Dengan demikian akan mengakibatkan proses fotosintesis berlangsung optimal. Pemanfaatan ruang kosong pada sistem tanam legowo menyebabkan proses fotosintesis berlangsung efektif pada fase generatif hasil fotosintesis lebih banyak dibawa ke biji sehingga hasil gabah lebih tinggi. 


\section{Berat Gabah Kering Per sampel}

Hasil analisis ragam menunjukkan bahwah terdapat tidak berbeda nyata antara perlakuan macam varietas dan sistim jarak tanam jajar legowo terhadap pengamatan berat gabah kering per sampel pada pengamatan umur panen.

Pada tabel 6, menunjukkan bahwa pengamatan parameter berat gabah kering per sampel menunjukkan tidak adanya interaksi pada macam varietas ciherang hal ini di duga bahwa tidak adanya perbedaan genetik dari masing-masing varietas sehingga masing-masing varietas memiliki ciri dan sifat khusus yang berbeda. Pertumbuhan ialah langka dalam kehidupan tanaman yang mengakibatkan perubahan bentuk, pertambahan berat, volume dan diameter batang dari setiap proses pertumbuhan, hasil dari pertumbuhan suatu tanaman dapat di lihat dari faktor-faktor pertumbuhan. Ada dua faktor penting yang berpengaruh dalam pertumbuhan suatu tanaman, yaitu factor gen dan factor lingkungan. Faktor genetik berhubungan dengan pewarisan sifat/perilaku tanaman itu sendiri, sedangkan faktor lingkungan berkaitan dengan kondisi lingkungan dimana tanaman itu tumbuh. Setiap varietas pada tumbuhan mempunyaii keunggulan yang berbeda dalam hal memanfaatkan sarana tumbuh dan keunggulan untuk melakukan penyesuaian lingkungan sekitar, sehingga berpengaruh terhadap potensi hasil tanaman.
Tabel 5. Rata-rata gabah kering per sampel (gram).

\begin{tabular}{cc}
\hline Pelakuan & $\begin{array}{c}\text { Rata-rata berat gabah } \\
\text { kering }(\mathrm{g})\end{array}$ \\
\hline V1 & $1.61 \mathrm{a}$ \\
V2 & $1.88 \mathrm{a}$ \\
V3 & $1.37 \mathrm{a}$ \\
\hline BNT 5\% & 0.61 \\
\hline
\end{tabular}

Keterangan : Angka-angka yang diikuti oleh huruf yang sama dalam kolom yang sama tidak berbeda nyata dengan uji BNT 5\%.

Hal ini sesuai dengan pendapat Pertamawati, (2010) yang menyatakan bahwa intensitas sinar matahari dan lama penyinaran cahaya dalam fotosintesis berpengaruh pada pertumbuhan (vegetatif) dan proses reproduksi (generatif) tumbuhan di dalam area tropis, lama waktu siang dan malam relatif sama, yaitu sekitar duabelas jam. Pengaruh tumbuhan pada fotoperiodik yang dapat mengganggu proses pembungaan, perkecambahan, dan perkembangan.

\section{Berat Gabah 1000 Biji Per sampel}

Hasil analisis ragam menunjukkan bahwah terdapat perbedaan nyata antara perlakuan macam varietas dan sistim jarak tanam jajar legowo terhadap pengamatan berat gabah 1000 biji per sampel pada pengamatan umur panen

Tabel 6 . Rata-rata Berat Gabah 1000 Biji Persampel (g)

\begin{tabular}{cc}
\hline Perlakuan & $\begin{array}{c}\text { Rata-rata berat gabah } \\
\text { basah per sampel (g) pada } \\
\text { pengamatan umur panen }\end{array}$ \\
\hline V1J1 & $29.30 \mathrm{bc}$ \\
V1J2 & $27.73 \mathrm{bc}$ \\
V1J3 & $29.63 \mathrm{~b}$ \\
V2J1 & $28.00 \mathrm{bc}$ \\
V2J2 & $29.20 \mathrm{bc}$ \\
V2J3 & $31.93 \mathrm{a}$ \\
V3J1 & $28.90 \mathrm{bc}$ \\
V3J2 & $28.37 \mathrm{bc}$ \\
V3J3 & $27.27 \mathrm{c}$ \\
\hline BNT\% & 2.07
\end{tabular}

Keterangan : Angka-angka yang diikuti oleh huruf yang sama dalam kolom yang sama tidak berbeda nyata dengan uji BNT 5\%. 
Pada Tabel 6, dapat dilihat bahwah terdapat perbedaan nyata antara perlakuan macam variettas dan sistim jajar legowo teerhadab jumlah berat gabah 1000 biji pada umur panen, Berat 1000 biji ini menentukan hasil setiap kualitas dari biji per perlakuan. Perbedaan berat 1000 biji setiap masingmasing perlakuan dapat di akibatkan ukuran biji dan isi pada setiap butir padi yang berbeda. Berat biji padi dapat dipengaruhi setiap faktor diantaranya yaitu: umur biji, waktu pemanenan, lama biji di lapangan sesudah masak, dan lingkungan. Jika di hubungkan dengan umur pemindahan suatu benih, semakin tua umur benih maka biomassa biji akan semakin menurun, hal ini dikarenakan pada setiap masa lama kesempatan pengisian biji menjadi lebih cepat sehingga akan dapat berdampak terhadap jumlah dan berat biji yang dihasilkan. Nilai tertinggi untuk berat gabah 1000 biji sebesar 31.93 (g).

Menurut pernyataan dari Chistanto dan Agung, (2014) bahwa pada umur benih muda berpengaruh terhadap peningkatan berat 1000 butir gabah seusai panen. Jika dianalisis lebih lanjut berat 1000 biji yang dihasilkan ternyata berkorelasi positif dengan anakan produktif yang pertama kali muncul. Pada perlakuan 0 HST dan 35 HST kemunculan anakan produktif lebih cepat sehingga diperoleh hasil berat 1000 biji lebih tinggi dibandingkan perlakuan 12 HST dan 21 HST. Pada perlakuan 12 HST dan 21 HST tanaman mengalami masa stagnasi 2-3 minggu sesudah

\section{DAFTAR PUSTAKA}

Aribawa, 2012. Pengaruh sistem tanam terhadap peningkatan produktivitas padi di lahan sawah dataran tinggi beriklim basah. Balai Pengkajian Teknologi benih dipindahkan sehingga mengakibatkan keterlambatan masa vegetatif. Berdasarkan hal tersebut, maka dapat ditarik kesimpulan bahwa kemunculan anakan produktif pada saat fase vegetatif berpengaruh nyata terhadap kualitas biji yang akan dihasilkan.

\section{KESIMPULAN DAN SARAN}

\section{Kesimpulan}

Kesimpulan pada hasil penelitian pengaruh Macam Jarak Tanam Sistem Jajar Legowo Dan Verietas Terhadap Pertumbuhan Dan Produksi Tanaman Padi (Oryza Sativa L.) sebagai berikut :

1. Adanya interaksi antara perlakuan sistem tanam sistim jajar legowo dan macam varietas pada pengamatan parameter tinggi tanaman ( 7, 21, 35, dan 49 hst), jumlah anakan (21,35,dan 49 hst), berat gabah basah per sampel, berat gabah kering per sampel, berat gabah 1000 biji per sampel.

2. Perlakuan sistem jajar legowo $4: 1$ dan varietas ciherang (V2J3) menghasilkan nilai yang lebih baik dibandingkan perlakuan lain.

3. Berat gabah basah per hektar pada perlakuan sistem jajar legowo 4:1 dan varietas ciherang (V2J3) adalah 10.40 .

\section{Saran}

Perlu dilakukan uji lebih lanjut sistim jajar legowo 4:1 dan varietas ciherang yang sesuai dengan lingkungan.

Pertanian (BPTP) Bali. Denpasar. Http// pertanian. Trunojoyo .ac.id

Azwir. 2008. Sistem Tanam Legowo dan Pemberian P-Stater pada Padi Sawah Dataran Tinggi. Balai 
Pengkajian Teknologi Pertanian (BPTP) Sumbar, Solok.

Christanto, H dan Agung, I.G.A.M. 2014. Jumlah bibit per lubang dan jarak tanam berpengaruh terhadap hasil padi gogo (Oryza sativa L.) dengan sistem of rice intensification (SRI) di lahan kering. Jurnal Bumi Lestari 14(1): 1-8

Christanto, H dan Agung, I.G.A.M. 2014. Jumlah bibit per lubang dan jarak tanam berpengaruh terhadap hasil padi gogo (Oryza sativa L.) dengan sistem of rice intensification (SRI) di lahan kering. Jurnal Bumi Lestari 14(1): 1-8

Hatta, M. 2012. Jarak Tanam Sistem Legowo Terhadap Pertumbuhan dan Hasil Beberapa Varietas Padi pada Metode SRI.

Husana, Y. 2010. Pengaruh Penggunaan Jarak Tanam Terhadap Pertumbuhan dan Produksi Padi

Ikhwani, et al. 2013. Peningkatan Produktivitas Padi Melalui Penerapan Jarak Tanam Jajar Legowo. IPTEK Tanaman Pangan. 8 (2): 72-79.

Mujisihono, R. dan T. Santosa. 2001. Sistem Budidaya Teknologi Tanam Benih Langsung (TABELA) dan Tanam Jajar Legowo (TAJARWO). Makalah Seminar Perekayasaan Sistem Produksi Komoditas Padi dan Palawija. Diperta Provinsi D.I. Yogyakarta.

Nursanti, R. 2009. Pengaruh umur bibit dan jarak tanam terhadap pertumbuhan dan produktivitas tanaman buru hotong (setaria italic (L.) beauv). Skripsi. Program studi agronomi. Fakultas pertanian. Institute pertanian bogor. Hal 27-28.

Pertamawati. (2012). Pengaruh Fotosintesis terhadap Pertumbuhan Tanaman Kentang (Solanum tuberosum L.) dalam Lingkungan Fotoautotrof secara Invitro. Jurnal Sains dan Teknologi Indonesia, 12 (1): 31-37.

Pratiwi, G.R., E. Suhartatik, dan A.K. Makarim. 2010. Produktivitas dan Komponen Hasil Tanaman Padi Sebagai Fungsi dari Populasi Tanaman. In: S.

Pujiasmanto, 2013. Perkuat ketahanan pangan nasional kita. Guru Besar Fakultas Pertanian Universitas Sebelas Maret (UNS). Surakarta. http://www.uns.ac.id.

Salahuddin, K.M., dkk. 2009. Response of nitrogen and plant spacing of transplanted Aman Rice. Bangladesh J. Agril. Res. 34(2) : 279-285. Diakses 19 Januari 2016.

Saragih, B. 2001. Keynote Address Ministers of Agriculture Government of Indonesia. 2nd National Workshop On Strengthening The Development And Use Of Hibrid Rice In Indonesia. $1: 10$

Sirrapa, P.M. 2011. Kajian Perbaikan Teknologi Budidaya Padi melalui Penggunaan Varietas Unggul Dan Sistem Tanam Jajar Legowo Dalam Meningkatkan Produktivitas Padi Mendukung Swasembada Pangan. Jurnal Budidaya Pertanian, 7 (2) : 79 86. 
Agroradix Vol. 3 No.1 Desember (2019)

ISSN : 2621-0665

Suprihatno, B. 2010. Deskripsi Varietas Padi.

Balai Besar Penelitian Tanaman

Padi, Badan Penelitian dan

Pengembangan Pertanian

Kementrian Pertanian Sukamandi 